Original Contribution

\title{
THE CHARITY IN MASLAREVO VILLAGE, VELIKO TARNOVO REGION IN THE PAST AND ITS REVIVAL TODAY
}

\author{
Bl. Stoykova ${ }^{1 *}$ S. Bozhanova ${ }^{2}$ \\ ${ }^{1}$ Faculty of Economics, Trakia University, Stara Zagora, Bulgaria \\ 2"Kiril i Metodii" Elementary School, village of Strahilovo, Veliko Tarnovo Region, Bulgaria
}

\begin{abstract}
It is assumed that one of the main characteristics of civil society ranks tradition of philanthropy and voluntary initiatives.

The article discusses the tradition of philanthropy and charity in the Bulgarian context based on its manifestations together a little village.

The problem with dealing the study is related to some specific actions of individuals to the collective interest to enhance public relations. Clarified and attitudes of local people about their experiences of giving and sponsorship. The data of the individual components are based on primary sources and are based on a survey conducted.
\end{abstract}

Key words: charity, sponsorship, the tradition of donating, Maslarevo, Veliko Tarnovo region

\section{INTRODUCTION}

It is widely accepted that the phenomenon of "philanthropy" is described through terms such as „benefaction," „patronage," „charity,” and „sponsorship" as each of these forms contains separate versions of the act of providing resources. In its nuances, benefaction is related to individual donations or backing by an individual person or organisation in the field of art, culture or education. Patronage is a donation, in which the name of the supporting organisation is featured in the specific performance or event of the organisation that received the donation. Charity is a gratuitous act of support, in which the resources are provided with expecting any benefit in return. From the perspective of the modern view, sponsorship is a kind of rewarding support, a deal of sorts, which entails the public advertising of the sponsor's name over the course of its implementation. (1)

Solidarity and acts of charity are the result of both sharing the established ethic norms in the community and a means of social integration. Such acts provoke researchers towards various

*Correspondence to: Blaga Stoykova, Department of Regional Development, Faculty of Economics, Trakia University, Stara Zagora 6000, Bulgaria, email: blaga_st@abv.bg aspects affecting one or other ethical and social norms. This study follows the tradition of charity events on the example of a small village, in which voluntary initiatives are well documented from the Renaissance to the present day. Our goal was to find the connection between the individual, its economic prosperity and its sensitivity towards social problems of the community.

\section{THE PHENOMENON OF "CHARITY" AND ITS HISTORICAL DEVELOPMENT}

The beginning of the popularisation of the work of charitable people was set in the year 1905 when the Minister of Education, Prof. Ivan Shishmanov Sava Velev gave the idea for the initiation of a "Golden book of donors towards popular education." The book was issued in 1907. Over the following years, studies in this field continued. Three tomes of this research were published. According to the researchers, these studies were useful, yet encompassed only a small fraction of the donations, which were primarily meant for fostering science and education. A special place was reserved for the founding and work of foundations and funds, which were active during the period from 1978 to 1951 . (2) 
In fact, from a historical perspective, charity has existed since ancient times when archaic societies maintained the belief that gifts, usually in the form of sacrifice would be returned to the donor through miraculous forces, in the form of protection by the deity (which has the power to regulate life within the society). This idea was recreated in well-known solemn contractual formulae - the Latin ,do ut des” and the Sanskrit "dadaml se, dehi me". (3)

The tradition of donating is sustainable and functional within the Slavic world. The sources indicate that, as far back as the pagan period, donations were made for personal events - in case of death or disease, for the purpose of healing and cleansing. Donations were most commonly done near water basins, forests, etc., and with time these cult sites were transformed into Christian holy places, usually related with the name of a certain saint. The paganistic and Christian models were strongly interconnected during the middle ages. Even though Christian morality did not oblige the faithful to make donations, there was an unwritten rule that more generous donations would yield greater divine favour afterwards. (4)

The researchers point out that during the middle ages donation evolved in its concept and strategy, gradually acquiring a statehood aspect. Personal motivation was joined by the ambition to affirm the state's authority and reinforce the sovereign's position by popularising their name among the subjects. Invoking the scriptures, the idea that the ruler was chosen and set in their place by God himself was imposed, along with the notion that their power is sacred in nature, which entails their obligation to act as a guardian and custodian of the Church. Thus rulers became the primary donors of the middle ages.(4)

Gradually, as a result of the formalisation of the Christian religion, one specific form of donation was imposed, known under the name of "church charity," which was related to the construction, ownership and support of a specific church or monastery. The normative regulation of church charity rights could be found in numerous documents of Christian legislature, such as the Nomocanon, The Basilicies, etc. Among the domestic source, a notable one is the preserved royal certificates of merit, such as the Votopedska, Virginska, Zografska, Mrachka, etc., as well as the preserved notes and mementos. It is interesting to note that the canons of the Universal Councils regulated the oversight over the activity of church donors. The ritualistic privileges of the donor were quite impressive, as they acquired the right to a place of honour in the monastery house, the right to be mentioned during service at the church within their area of charity, the right to be buried inside the church, to have a representative portrait among the murals, as well as a place of honour during processions. (4)

During the age of Enlightenment, support and charity were related to printing books and study aids. Thus, gradually, thanks to the monetary generosity of donors, was printed the first newly printed book in spoken language "Kiriakodromion. Meaning: Nedelnik" (1806), "Book of various teachings" (1824), "Bulgarian folklore songs"(1861), etc. (5)

After the Crimean war, Bulgarian enlighteners and the Bulgarian emigrants in Odessa, Bolgrad, Chisinau, Galatz, Bucharest, Braila, Belgrade, Wien, Istanbul and elsewhere were united around the idea of creating a Bulgarian centre for literacy. The formation of the Bulgarian Literary Organisation in Braila was related to the name of the renowned enlightener of the Revival era Vasil Dimitrov Stoyanov. The programme for the implementation of this idea was outlined together with Marin Drinov. V. Stoyanov's talks about the goals and tasks of the literary organisation among the emigrants in Romania and a number of Bulgarian towns attracted supporters among the Bulgarian merchants and entrepreneurs, who provided the funds for its creation and maintenance. The first donors were named "supporting members" of the BLO, and the size of their contribution divided them into "custodial" and "meritorious." (6)

After the Liberation, Prince Ferdinand initiated in 1895 a country-wide signature gathering and issued a rescript for the collection of funds for the composing of the first Bulgarian encyclopedia. The collected funds were planned to be invested into issuing a series of books on geography, demographics, flora and fauna, culture, etc., for the "complete description of the Bulgarian people and land." A committee was formed at the Ministry of Popular Education, which would gather the resources and assign the writing of the works from the encyclopedic series, which was called "Bulgarian fatherland." (6)

Numerous monetary funds were created during this period, among which one of the first was the 
one founded by Hristo G. Danov (1906). One of the largest funds was "Dobri Ganchev," which was founded in 1936 and was formed from donations of shares and obligations. It is also interesting to note that in 1937, the "Golden Book of Donors" issued by the MPE listed about 45 charitable funds, and in 1951 there were about 60 of them and they counted among the most significant donations and funds of the Sofia University, the Holy Synod and the unified funds "Testators and donors" at the MPE. (6)

In 1944, according to K. Velichkova (Executive Director of the Bulgarian Charitable Forum), the total number of foundations, associations or organisations with so-called "eternal capital" reached about 900, with the capital being appropriated by the state in 1951. (7) In a series of ordinances and laws passed during the period 1948-1949 - the Budget and budgetary accountancy act, the Budget of the PRB for 1948 act, the Persons and Family act, etc. - the activity of all funds originating from inheritances and donations was shut down. Through a Regulation on social support (Art. 17), published in September 1951, all associations and foundations were obliged to terminate their work within three months and submit their property to the People's Councils and their monetary asset to the Council of Ministers. (2) During the next few decades, there are practically no official acts of charity.

The concepts of charity, as well as citizen participation began to resurface slowly and with difficulty after the year 1989. (8)

Currently, the reborn charity is related primarily with corporations and companies, various organisations, which determine grants for the fostering of charity, as well as with individual natural persons. Corporate social responsibility is a positive trend as well. The period from 2000-2002 has been pointed out as the initial period in the establishment of working partnerships between companies and NGO's for the creation of a culture of corporate charity and marketing engaged with a social cause. The process, according to some researchers, is related to the UN's global initiative and the fostering by the EU, which was the reason Bulgaria created the code of ethics of the Bulgarian Forum of Business Leaders, as well as the founding of the annual awards for socially responsible business. Another step in this direction was the creation of the Bulgarian Donors' Forum in 2003. (9)

Towards the end of the $\mathrm{XX}$ and the beginning of the XXI century, charity in Bulgaria marked a positive development. Donations support social institutions, vulnerable social groups, etc. Today's primary mechanisms of charity are: corporate social responsibility, amounts given by donors, payroll donations, as well as SMS campaigns through text messaging.

An interesting trend of charity in Bulgaria is that, for the most part, it is done quietly, without public announcement in the media. Some authors see the reason for this in the deep-rooted understanding that one should not boast with donations. (10)

\section{HISTORY OF CHARITY IN THE VILLAGE OF MASLAREVO, VELIKO TARNOVO REGION}

The building of a church with the aid of the entire population of a settlement is a sign of spiritual revival.

The cell, which was built two-three years before the church, so that the school could be moved into it as it was previously within a private home, was the work of the Bulgarian populace in Maslarevo, even before the Liberation. Bulgarians bought the yard and gave it for the construction of a cell (and after that - a church). The construction work was performed by volunteers, who laboured willingly. The stones were delivered from other villages. The whole populace took part in the construction.

The primary managers and organizers of the construction of the church were Nedyalko Vachev and grandfather Radko. Nedyalko Vachev personally brought the chandelier from Russe on his back over three days. (11)

The church was opened on November 8, 1864 (Dimitar's day). (11) Even today, Dimitar's day is celebrated as the village's holiday.

The first church books were also collected through donations. Some of them were sent by the Moscow Slavic Committee and were distributed from there (including for Maslarevo). These were: a gospel printed in Slavic letters in 1865 in Russe, an apostle in Slavic language printed in Istanbul in 1856, as well as an old capital gospel, also printed in Istanbul in 1857. (11)

There are also interesting acts of volunteering related to the opening of a culture home in the village. After the Liberation, by the initiative of Aleksandar Popivanov, the teachers organised evening meetings and gave performances. In 
1902, the first performance of "Hadzhi Dimitar and Stefan Karadzha" was staged, and the collected BGN 120 were saved for the construction of a culture home. (11)

After the growth of the so-called cooperative movement in Bulgaria, a number of philanthropic acts could be seen in villages.

On January 20, 1908, by the initiative of the teacher Aleksandar Popivanov, along with Gosho Radkov and the freedom fighter Gancho Dimov, a mutual savings agricultural association was founded by 23 people. After the cooperation's founding, its Statute was accepted on January 30 and it was published in the State Gazette on March 5, 1908. The primary goals set by the company were to support the material, intellectual and moral behaviour of its members; to find and procure the necessary capital for their needs in agriculture and its branches, in accordance with their credit capacity, and to develop and expand the savings among the members and other villagers.

The cooperation took a credit and purchased new ploughs, performed group deliveries of vinegar, gas, salt, agricultural inventory, etc. The cooperation managed to create its own library quite rich for its time. In 1928 they also purchased a thresher, yet in the next year, 1929, a devastating hail ruined the crops of the village. Because of this, the management of the cooperation sent the thresher to other villages, which had not been affected y the hail. A large part of the gathered food from the threshing was given to the co-operators, so that they would not starve. (11)

During the totalitarian period, after the creation of the LCAF (Labour-Cooperative Agricultural Farm) two bans for the livestock were needed, so the local Komsomol organisation formed a special brigade and thus all young people worked for free within a month, making bricks. By the end of 1950, two barns and one shed for 1000 sheep were built. However there were not enough tiles to cover the shed. The local communist party organisation decided that every communist would "voluntarily" remove two rows of tiles from their own house or shed and submit them for the completion of the sheep shed. All cooperation members were urged to follow this example. This is how the tiles were gathered through mutual efforts. (11)
During the village's electrification, a large part of the populace took part voluntarily in the casting of the poles. In the winter of 1956-1957, the village was developed through mutual efforts. On January 30, 1957, the first electric light bulb was lit in the village of Maslarevo. (11)

Water supply was provided in a similar manner. The whole populace took part once again. Each villager voluntarily took the obligation of digging the canals that would pass near their yards. If the people were too old to handle this task, they were assisted by the younger villagers. In 1966 the water supply of the village of Maslarevo was finished. (11)

The collective care and responsibility of the villagers were also observed after the earthquake on March 4, 1977 when a local was trapped under the ruins of the LCAF building. Volunteers cleared the debris all night long, in order to find the place where the person was trapped. Thus he was successfully rescued. (11)

An object of interest to the current study was also the so-called social mutual help, in which relatives, neighbours and fellow villagers help each other. In the village, this kind of support is known to be gratuitous as well as with expected return. Towards the end of the XIX century up to the mid-XX century there had been a custom to take turns at the different houses during the threshing. They also helped each other during grass-mowing. Villagers also id each other favours with livestock - for carrying bundles from the fields or lumber from the woods. The women also helped each other with the household work. They gathered for grinding and peeling work, and in the winter - for spinning and any other kind of work. (12)

The villagers also helped each other while building houses. Assistance was given not as much in the form of inventory as in labour.

In more recent times, after 1990, the Pentecost feast tradition was restored at the villages. Money are collected as donations and used to purchase a lamb, which is then used for the preparation of the boiled mutton. Prayers are said for good health and an annual village celebration is organised. The tradition has lasted for more than 20 years now.

During the current decade, the acts of charity for the maintenance and restoration of public 
buildings have re-emerged. This is how, for example, in the summer of 2012, the last major renovation of the church was performed. Within the church interior, the space under the dome was reinforced, and cement pathways were laid outdoors along with an open ground in front. The major donors of funds for the renovations were Ivan Sabev and Svetla Nikolova who donated about BGN 5000, Ivaylo Pavlov - about BGN 1000 and the cooperation "Saglasie 93" - BGN 300 . The renovations were performed entirely with the voluntary labour of Valentin Todorov from the village of Maslarevo and Petar Hadzhiev from the town of Pleven.

In March 2014 a rose garden was planted by Valentin Todorov and Silviya Nikolova.

\section{SURVEY OF THE ATTITUDES AMONG THE POPULACE OF THE VILLAGE OF MASLAREVO, VELIKO TARNOVO REGION, ON THE PERFORMANCE OF CHARITABLE ACTS}

The data from the separate components in the present study are based on primary sources and are founded upon a survey conducted with the assistance of a questionnaire addressed to the inhabitants of the village of Maslarevo, Veliko Tarnovo region.

As a result of stratification on the grounds of randomly selected permanent inhabitants of the village, a research sample was formed, along with 37 successfully conducted surveys.

1. Methodology and collected information The study is based entirely on primary sources of data. The empirical material was collected through a direct standardised interview per a questionnaire made in advance.

\section{Target group}

The survey encompassed the permanent inhabitants of the village of Maslarevo, Veliko Tarnovo region. The captured snapshot is indicative for the condition of their attitudes regarding the acts of charity and sponsorship. The alteration in the social-economic parameters

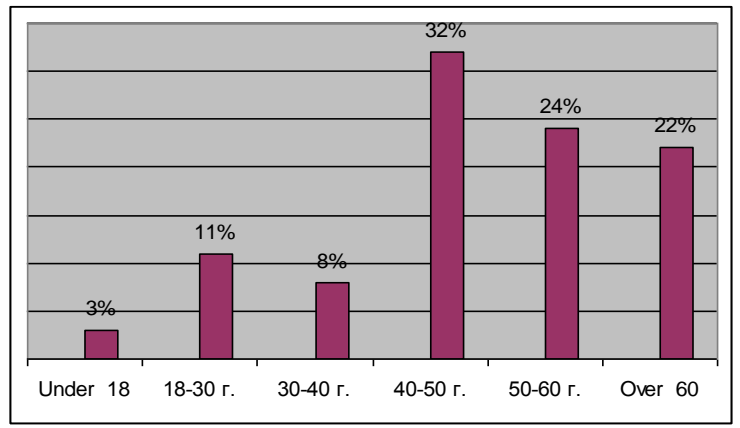

Figure 1. Age can be easily detected on the basis of the acts of philanthropy in its various forms that have been observed thus far, as well as participation in a number of volunteer initiatives. The change in the status quo throughout the different historical periods of the settlement's development allows for drawing conclusions regarding the ties between personal motivation with socialeconomic development, mentality and way of life.

\section{Questionnaire content}

The questionnaire that was used for the conducting of the survey consists of two parts.

The first part examined the demographic profile of the participants, as well as their social and economic status.

The second part examines the attitudes of the populace regarding acts of assistance, as well as the amount and preferred ways of gratuitous provisions of resources.

The respondents who took part in the survey encompassed a very wide range of ages from 18 to over 60 years old. Regarding gender - the men to women ratio was reciprocal. (Figures 1, 2)

The results of the survey indicate more than $57 \%$ of the respondents had secondary education. (Figure 3)

The majority of the interviewed persons indicated a monthly income of BGN 300, 27\% between BGN 300 and 500, and only 5\% had an income between BGN 500 and 1000. Even though $20 \%$ did not respond to the income level question, the figure clearly shows the populace's low incomes. It is interesting to note that in this case social inequality does not play a role in the performance of charitable acts. (Figure 5)

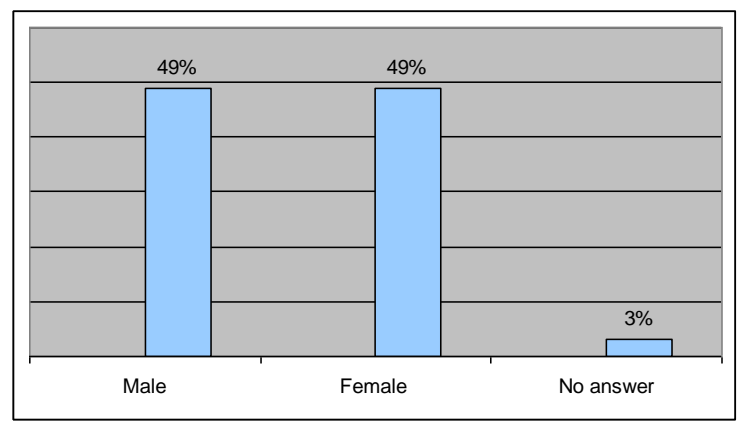

Figure 2. Sex 


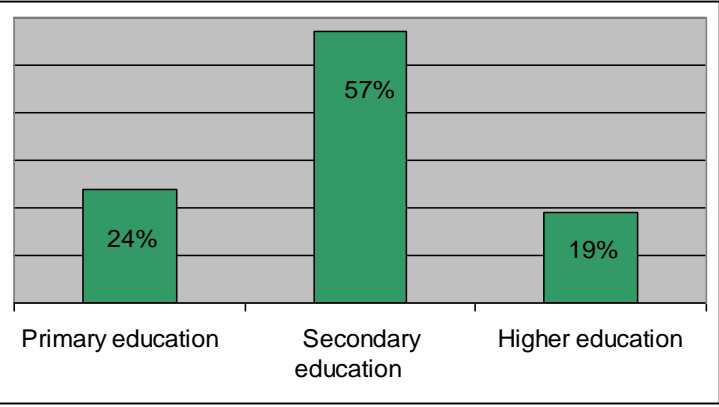

Figure 3. Education

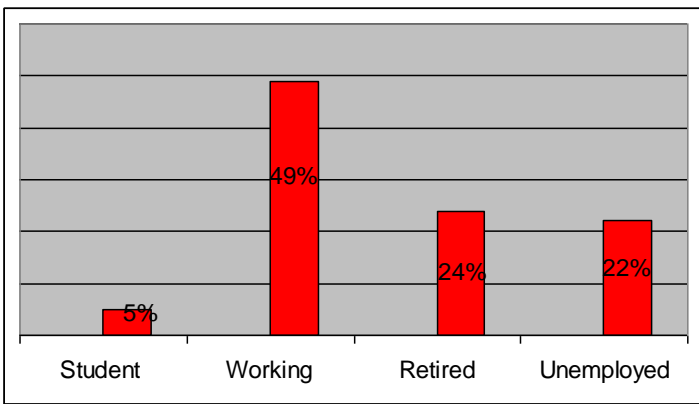

Figure 4. Social status

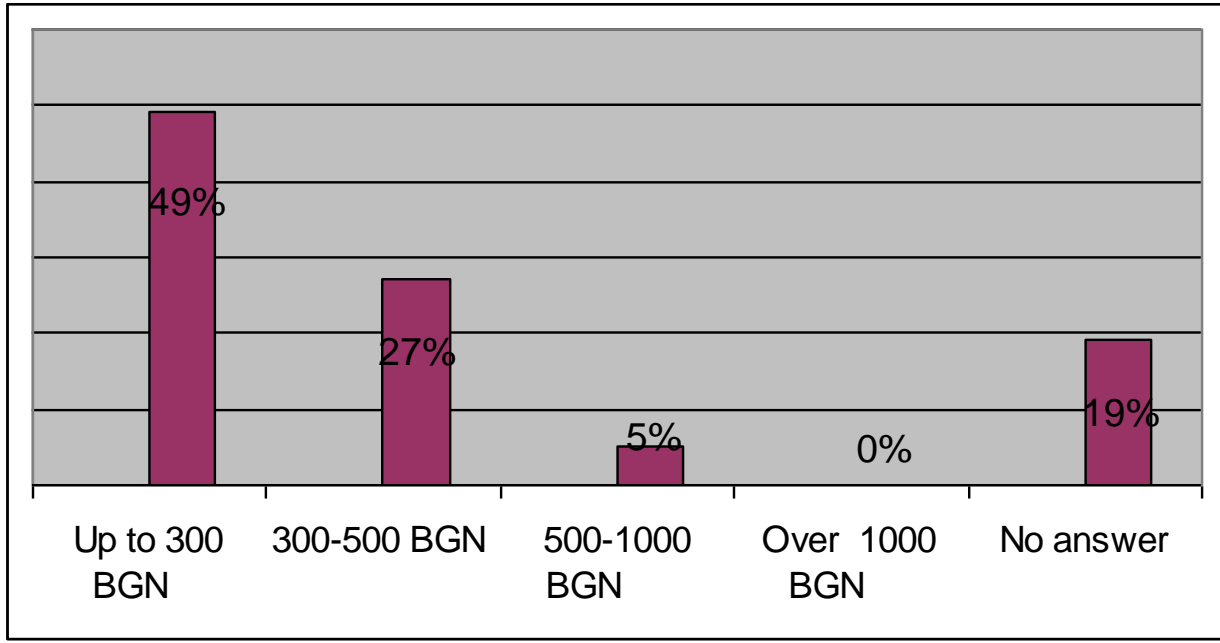

Figure 5. Monthly income

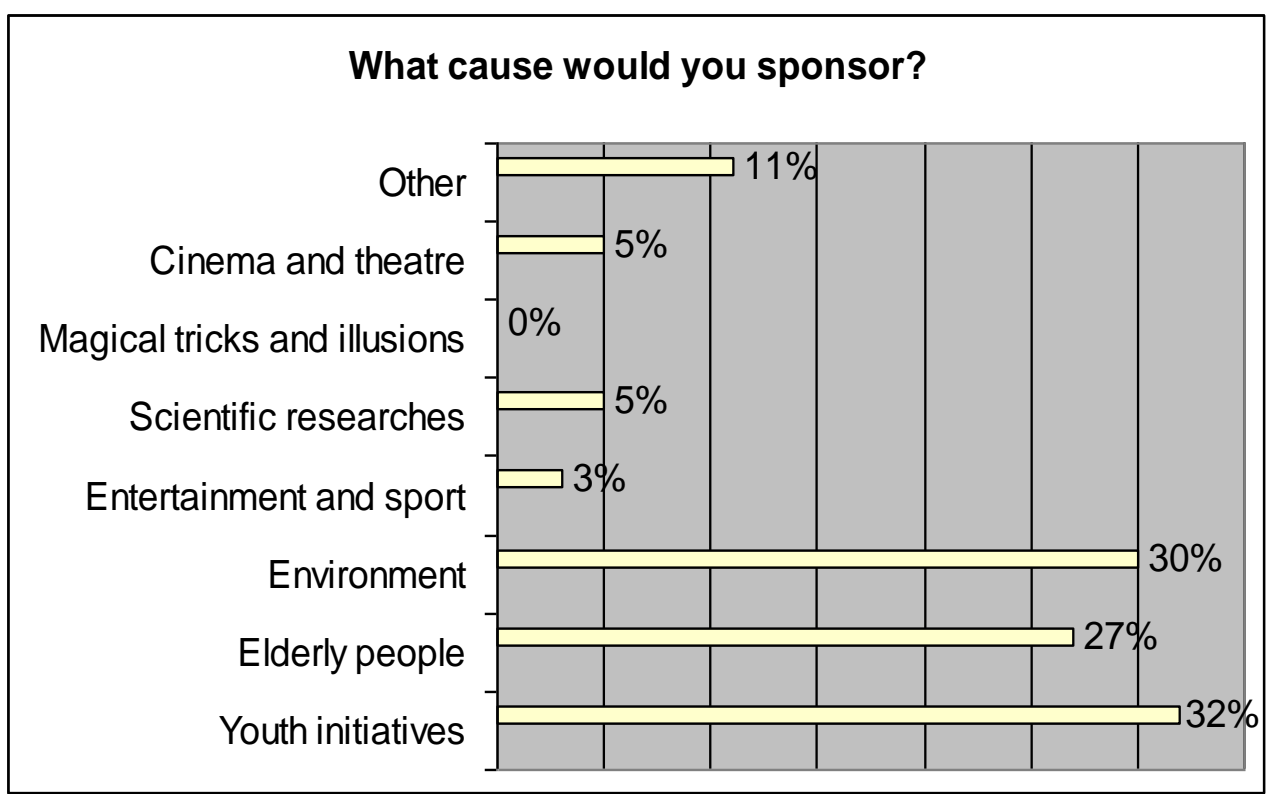

Figure 6. Possible cause for sponsoring

The results regarding the type of cause the respondents would donate towards were undoubtedly surprising in terms of variety. $32 \%$ declared that they would donate for youth initiatives, $30 \%$ for the environment, and $27 \%$ for elderly people. Groups of $5 \%$ would donate for scientific research and for cinema or theatre, and 3\% for entertainment and sport. (Figure 6) 


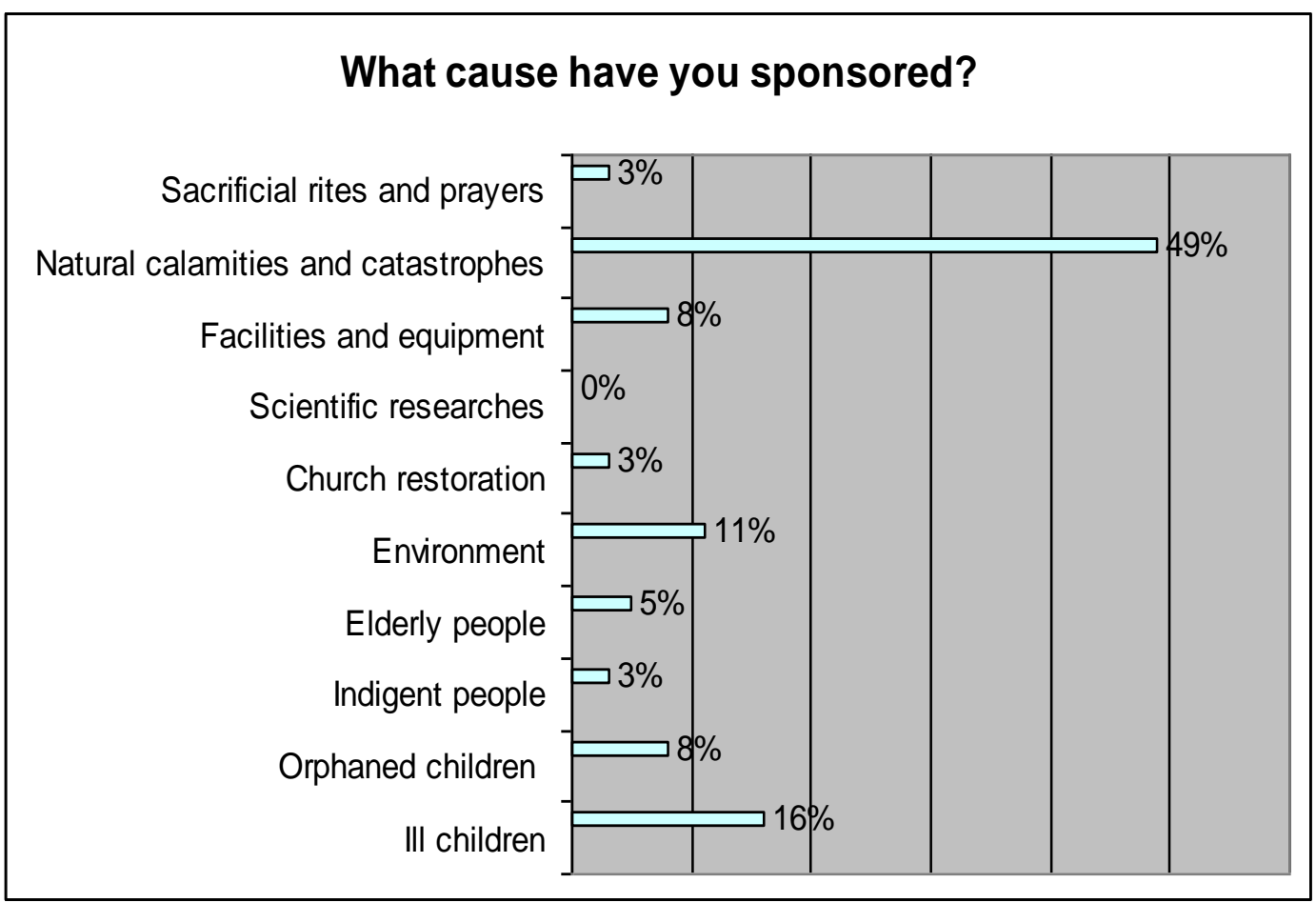

Figure 7. Already sponsored cause

The populace donated the largest amount of funds for overcoming the consequences of natural calamities and catastrophes - $49 \%$, followed by $16 \%$ for sick children, and $11 \%$ for a clean environment. (Figure 7)

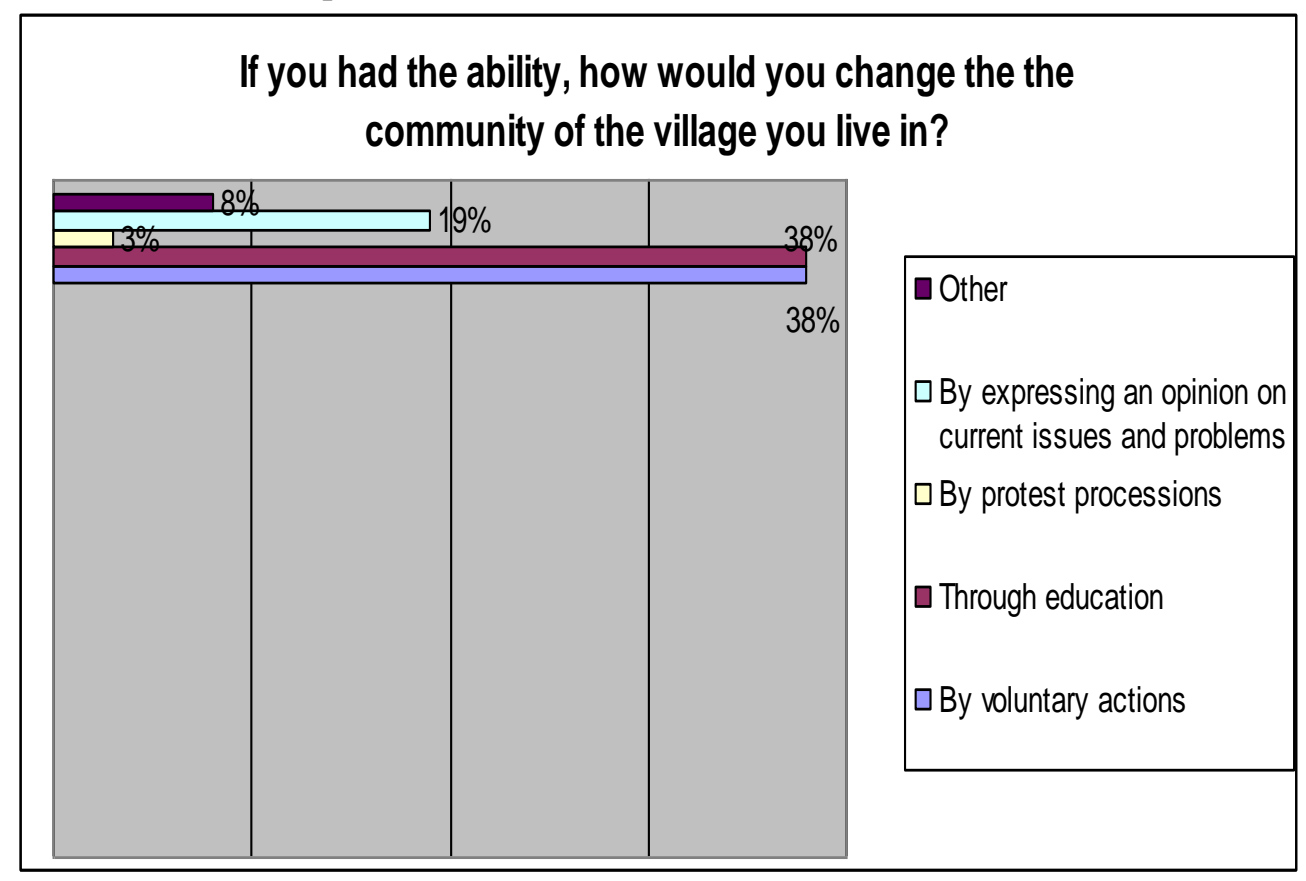

Figure 8. Wanted change the community of the village

The surveyed persons declared highest readiness for participation in voluntary actions with the purpose of changing the community of the village they live in $-8 \%$. The same percentage also declared that this could best be achieved through education. (Figure 8) 


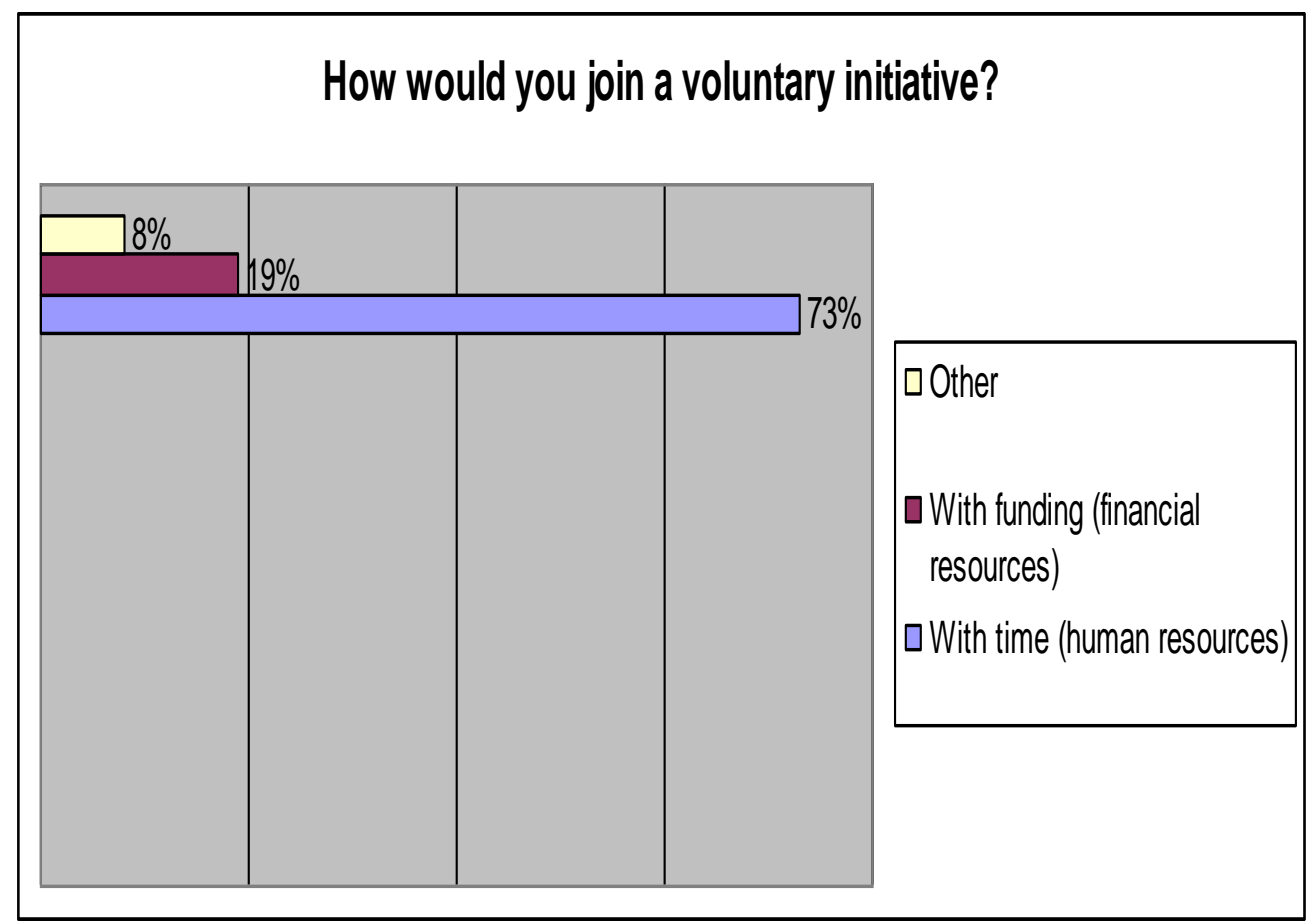

Figure 9. Possible way of joining a voluntary initiative

Participation in a volunteer initiative with time (human resources) was declared by $73 \%$ of the respondents. $19 \%$ declared that they would allocate funds (financial resources). (Figure 9)

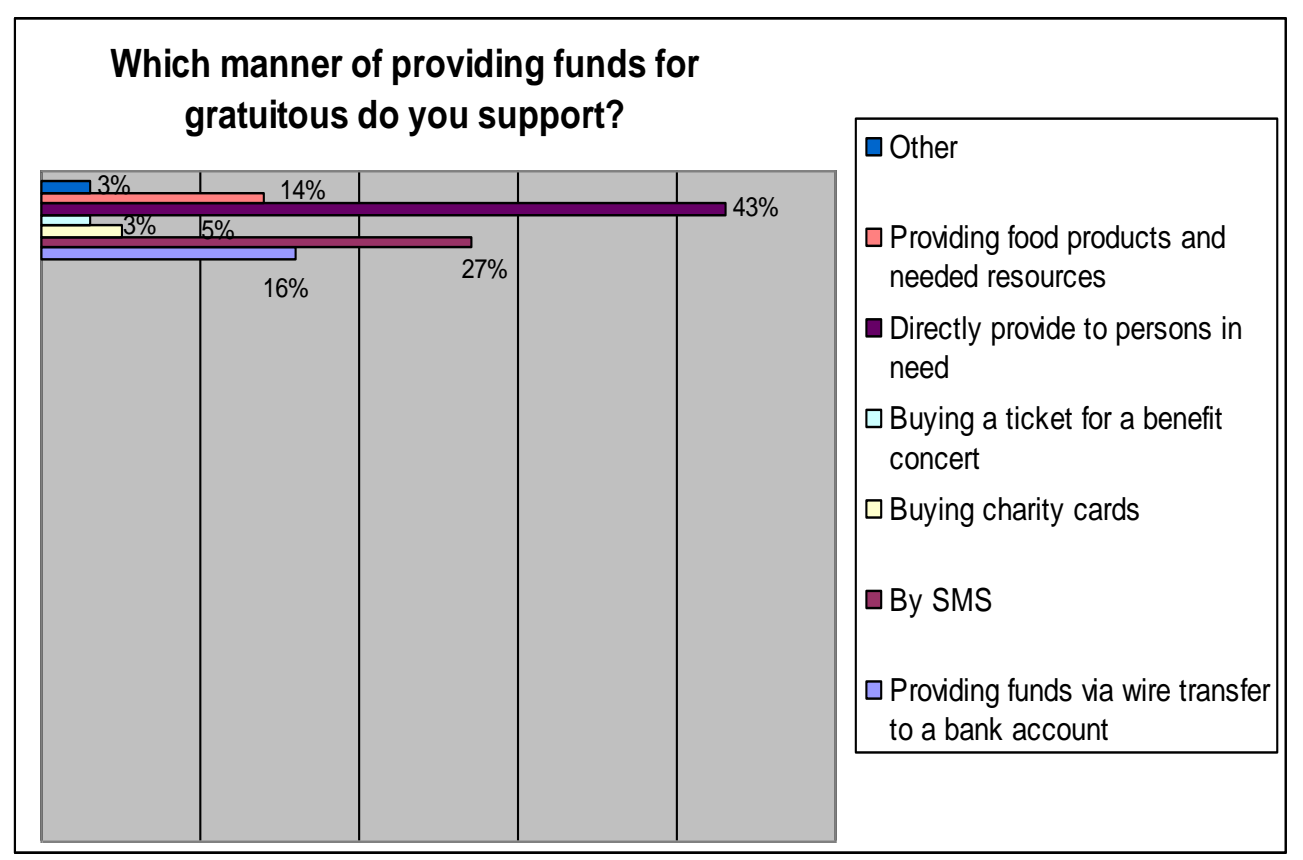

Figure 10. Supported manner of providing funds for gratuitous donation

Regarding the manner of providing funds for gratuitous support, the predominant preference was to directly provide them to persons in need $43 \%$, followed by SMS campaigns $-27 \%$ and provision of food products and needed resources $-14 \%$. The lowest percentage declared that they would provide funds via wire transfer to a bank account - only $3 \%$. (Figure 10) 


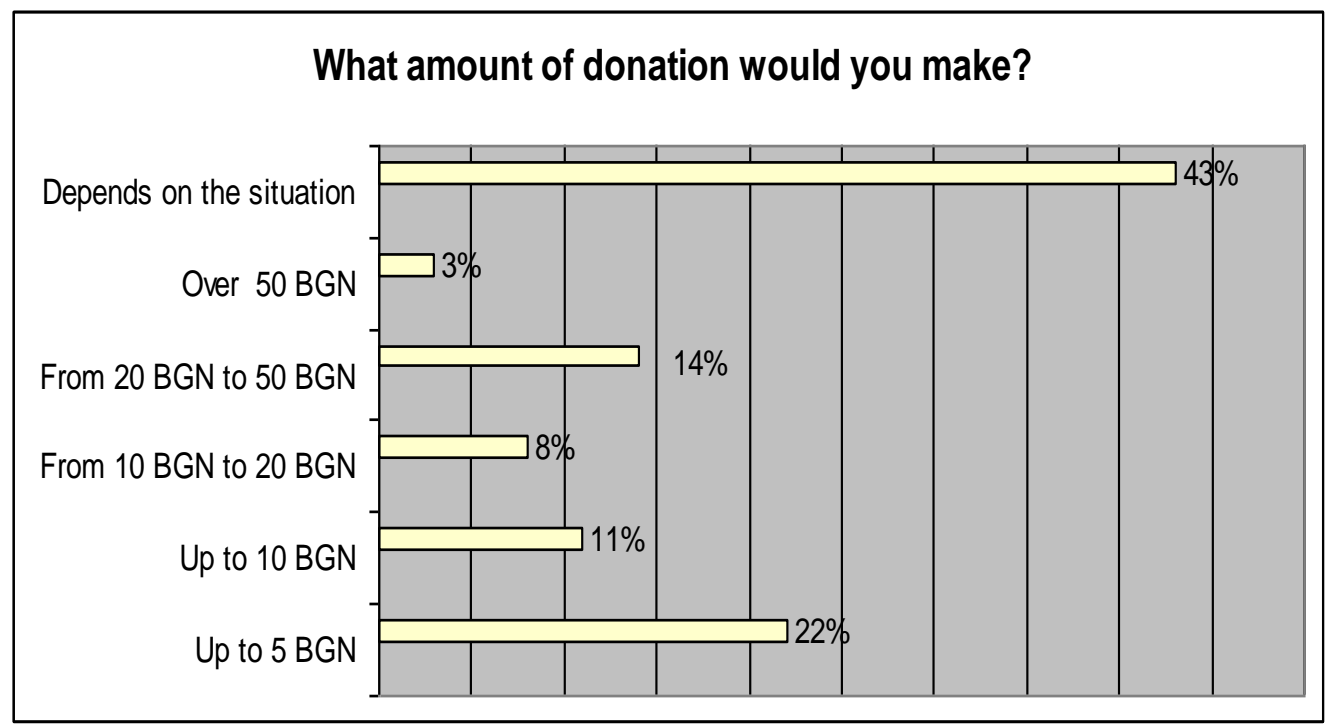

Figure 11. Possible amount of donation

Regarding the amount of the donation, the predominant opinion was that the amount depends on the situation $-43 \%$. The highest percentage of the respondents would donate BGN $5-22 \%$ and the fewest people would donate over BGN 50 - only 3\%. (Figure 11) Undoubtedly, the bilateral connection between economic condition and charitable acts comes to the forefront. The response to this question corresponded directly to the results from Figure 5, which demonstrated the predominantly low income levels of the interviewees.

\section{CONCLUSIONS AND \\ RECOMMENDATIONS}

It is accepted that one of the primary features of civil society is the tradition of charity and charitable initiatives. Currently, the results of charitable causes organised throughout history are visible to everyone - built schools, churches, culture houses - created through the initiative and help of people from various layers of society and with varying education, whose life paths were intersected by the ideas of supporting the members of their society in any way they could.

- The discussion makes it clear that a tradition has emerged in the village of Maslarevo, Veliko Tarnovo region, which has not been broken over the course of its historical development from the National Revival era to present day, despite the political disturbances of the past. The idea of "for the people's benefit" gave birth to educational and cultural institutions, which continued to have a leading role in the local community. Unfortunately, due to the circumstances and in line with the realities of the time and the new political situation in 2010, the elementary school in the village was closed and the voices of the students are no longer heard in the schoolyard. However, the people's culture home still has an important place in the village's cultural life. A number of initiatives were organised thanks to it, which are still supported and assisted by the local community.

- Charity and volunteer initiatives as an act of altruism are related to the individual's desire to show compassion and not stay indifferent to the problems of society or the personal misfortunes of separate members of the community (including sick children, elderly people, victims of natural disasters, etc.)

- The charitable drives and campaigns organised through a number of means for mass information (mostly television) provoked compassion among the local populace by posing the choice of donation a portion of their meager income.

- During the last few years of a severe economic and social crisis, the desire and necessity to donate to people in distress did not exhibit any relation to economic wellbeing. Charitable acts do not depend on the economic status of the donor, even though there can be a mutual relation between their actual income and the amount of the 
donated amount. It is interesting to note that the persons with lower income transformed their necessity of charitable acts into voluntary labour.

- Sensitivity to social problems is the most incredible social capital that a community can have at its disposal. $\mathrm{T}$ is interesting to note that the local populace donates money with the highest regularity for the organisation of celebrations for health and success of the community. Donating money in this occasion is considered to be a matter of personal dignity. This charitable act is mostly perceived as a form of social integration.

In conclusion, in the village of Maslarevo, Veliko Tarnovo region, generations of inhabitants, facing the challenge of donation, discovered the values and principles, which formed them into a patriotic community that preserved its national culture and honour throughout the centuries.

\section{REFERENCES}

1. Borisova, S., Philanthropy - the art of giving, Medii i reklama, S., March, p. 33, 2000.

2. Encyclopedia of charity. Charitable funds and foundations in Bulgaria 1878-1951, S., 1: 11-15, 2011.

3. Moss, M., Donation - form and grounds of exchange in archaic societies, S., 2001, p.
65, quoted per Genova-Kalpakova, S., Charity and church donations in mediaeval Bulgaria - theoretical basis, Minalo, S, 4: 10, 2005.

4. Genova-Kalpakova,S., Charity and church donations in mediaeval Bulgaria theoretical basis; Minalo, S, 4: 11-19, 2005.

5. Dimkov N., On the first assistance and charity during the National Revival era, Annual book of the Shumen University "Episkop Konstantin Preslavski" ( XV A), Sh., p. 87, 2000.

6. Velichkova, Tsv., The contribution of the first donors towards the development of Bulgarian science and its institution; Nauka, S., 4: 39-40, 2009.

7. Dimitrov, V., Vision of philanthropy, Forbes, Bulgarian S., October, 7: 21, 2011.

8. Kabakchieva, P., The many faces of charity, Charity in contemporary Bulgaria. Anthology, S., p. 13, 2011.

9. Hristova, D., Charity and civil participation, Charity in contemporary Bulgaria. Anthology, S., p. 46, 2011.

10. Gercheva, V., Pay it forward, Capital, 2329 April, S., pp. 26-27, 2005.

11. Atanasov, Zh., Maslarevo, S., 1988

12. Stoykova, B1., Maslarevo at the end of the XIX - beginning of the XX century (historical-ethnographic study), V. Tarnovo, 2007. 